Psycho-analysis, Sleep, and Dreams: By Axdré Tridox. Pp. xii + 161. 1921. London: Kegan Paul, Trench, Trübner \& Co. Ltd. rs. 6d. nct.

'TuIs little volume is written for the general reader, and though it contains some observations of interest, it cannot be regarded as a significant contribution to the subjects with which it deals. The author advances the thesis that we sleep in order to dream and to be for a time our simple and umrepressed selves. He endeavours to support this more than doubtful thesis by suggesting comparisons between sleep and certain morbid conditions - notably, sleeping sickness. In describing this disorder as a neurotic manifestation, occurring in circumstances which make a flight from reality highly desirable, the medical reader will probably fecl that Mr. Tridon is unduly stressing the influence of emotional factors in the production of physical illnesses.

\title{
H. IEVINE.
}

Addresses on Psycho-analysis. By. J. J. P(trial, M.I)., Emcritus Professor of Neurology, Harvard University. With a Preface by Signund Freud. The International Psycho-analytical Library, No. 1. Roy. 8vo. Pp. $v+475$. 1921. London: George Allen \& Unwin Ltd. 12s. 6d. net.

THIs volume consists of selections from the psychological writings of Professor James J. Putnam, the eminent neurologist of Harvard University, who died in 1918. In his later years Putnam became convinced of the importance of Freud's teaching, and soon became its chief American exponent. The extent of his interest in the subject is shown by the lengthy bibliography of his psycho-analytical lectures and writings, compiled by Dr. Ernest Jones, the editor of this new series, for inclusion in this rolume. These addresses are not highly technical, and they are evidently intended to be explanatory of the wider principles rather than of the details of psycho-analysis. Though written with frankness and courage, their tone is persuasive and tentative rather than dogmatic, and they are pervaded by a spirit of sincerity, tolerance, and kindliness.

Dr. Putnam was an excellent critic, and he provides a valuable and well-balaneed account of the various schools of thought which have broken away from, and developed out of, the original teaching of Freud. He shows an understanding attitude towards these schismatic groups, and his criticisms are all the more foreeful as he was fully alive to, and not entirely unsympathetic towards, the reasons which made a break almost ineritable. Though Dr. Putnam retained his conviction of the truth of the details of psycho-analysis, his strong philosophic leanings led him to differ from Freud on certain vital points. He was unable to aceept either the pleasure-pain principle or the strictly deterministic theory of human behaviour. In some respects his views approximate somewhat elosely to those of Jung, though he was unable to understand the rejection by the latter of the theories of repression, fixation, and infantile sexuality. He evidently felt that the human being could not be adequately interpreted 